\title{
LEGALISING SAME SEX MARRIAGE AND CLONING: A NEED FOR ETHICAL CONSIDERATION
}

\author{
Gloria Faith Ehiemua* \\ \& \\ Lateef Kayode Adeyemo* \\ http://dx.doi.org/10.4314/og.v13i 1.4
}

\begin{abstract}
This paper examines the objectification of persons using same sex married couples situation. It argues that the legislation of same sex marriage creates "artificial infertility" and promotes dependency on cloning for procreation of genetically related children. The aim of this work is to highlight the legalisation of same sex marriages as "creating a pool of infertile persons" for purposes which go beyond the happiness of same sex couples. The methods adopted are analogical, casuistry and normative. Arguments put forward use same sex married couples situation to buttress the objectification of infertile persons in human cloning. The finding shows a relationship between the legalisation of same sex marriages and cloning. The work concludes that the ban on human cloning should not be lifted since self inflicted harm must be avoided.
\end{abstract}

\section{Introduction}

At first, human cloning and same sex marriage may not seem related. However, the legalization of same sex marriage deepens the link between human cloning and same sex marriage. Cloning is one of the reproductive options available to same sex couples who may wish to have their own children. Naturally, two men or two women cannot procreate. On this basis, same sex marriage is regarded as no marriage but a delusion. In Parella's (2004) view, "the bonding of the male and female, whole in themselves add up to more than "one", they enrich each other through their "complementarity." The basis for legalizing same sex marriage is anchored on its seemly acceptability in recent times. Moreover, infertility which posed as an obstacle can be overcome using assisted reproductive technology such as artificial insemination, in vitro fertilization and cloning. Surrogacy and adoption are also other methods that can be employed. 
Infertility is a serious problem for homosexual couples. Marriage between same-sex is naturally opposed to procreation. Although, society and technology have created avenues through which same sex couples can have their own children, cloning remains the only viable means through which same sex couples can have genetically related children because of what it is - a duplication of the original. Presently, there is a ban on human cloning for reasons that include safety of human beings. A lot of people are of the view that, human cloning and the process of developing it, involve creating, manipulating, injuring and killing members of the human species that is, human beings. However, a ban on cloning constrains two important liberties- freedom of reproduction and freedom of science (Shalev, 2002).

With the passing into law of same sex marriage in certain countries around the world, cloning as an option to the problem of infertility may be reconsidered. According to John Robertson (2005), cloning would appear to fall within the fundamental freedom of married couples including infertile married couples to have biologically related offspring. Medical research using human subjects according to Shalev (2002) may be conducted if its objectives and potential benefits outweigh the inherent risks and burdens to the participants. Cloning performs certain functions which make it alluring to same sex couples who push for equality. For instance, the ability to have genetically related children might be the needed proof that same sex marriage is not different from heterosexual marriage. Cloning is also an ideal for lesbian couples who may not wish to have anything to do with the male sex. It does not require sperm for reproduction and it affords lesbians the opportunity to reproduce only girls if they want to. The need to fulfill these desires produces a market for companies with the technological knowledge. Thus, every interested company wants to be the first to acquire the technological know-how, because, it translates into plenty of money. It has been asserted that many biotechnology companies look forward to multi-millions of dollars in the hope of developing cures for various diseases from cloning human embryos. Government benefits from this arrangement as it clutches at the power, fame and prestige that comes with being the first to have a breakthrough in the technology among other competitors. 
The act of legalising same sex marriage recognizes the arrangement of man to man or woman to woman marriage as acceptable. It accords gay couples the much needed respectability and empowers them with the authority to fight for the right to procreation. As responsible adults, they can make choices, take decisions and give consent while bearing the responsibilities of such actions.

For biomedical scientists, the goal pursued is to increase knowledge and understanding of living nature as well as, to help the sick and the suffering. Researchers in this field predict that by the year 2020, ninety-five percent of human parts will be replaceable with laboratory grown organs (Williams, 2007). However, scientific research in its nature is not theoretical but experimental. Cloning, for research and therapy requires a large number of donor oocytes. This donation involves various risks and discomfort (Stanford Encyclopedia). It is observed, that given the risks to donor, the absence of direct medical benefit for donor, and the uncertain potential of cloning research, the number of altruistic oocyte donations for such research is low (Stanford Encyclopedia). Williams (2007) is of the view that scientists have the technology. What they do not have is permission from government or sanctions from the public to experiment with cloning human beings.

According to David Schneider (n.d), a democracy is designed to facilitate a balance between competing interests, to achieve maximum benefit for the maximum number of its citizens. Legalising same sex marriage seems to create the opportunity for a balancing of interests in human cloning situation. Same sex couples are construed as infertile endangered species whose interest and rights to procreate should not be undermined. The push for this group of persons to have a "functional marriage" which by societal standard, is through procreation,could make them consent to participate in research on human cloning in order to produce genetically related children. By consenting to participate in human cloning research, they endorse scientists with the authority to experiment and perfect the science of human cloning. A breakthrough in human cloning establishes a booming market for biotechnological companies while bestowing prestige and power to whichever country with the first success story. The question is, can this consent be said to be true consent and can the creation of an 
infertile community to foster the interest of an advantaged group be said to be justified in the quest for long life and the desire to experiment?

This work examines the philosophical theme "objectification" in same sex procreation. It argues that the legislation of same sex marriage projects justifies same sex married couples as infertile and make them dependent on cloning for procreation despite the harm on human beings. The process of cloning is dehumanising and the act objectifies infertile couples, who are used as instruments for furthering scientific research and other gains of cloning technology. The question begging for answer and apposite to our study therefore, is, "can man work against his nature and still retain the nature of his humanity?"

\section{Marriage, Religion and Feminism}

In every society, marriage is approved as a platform for procreation and child rearing. It is regarded as important because it plays a major role in the continuity and survival of any society. In fact, no society has ever prosper with its decadent family system. Traditionally, marriage is between a man and a woman but with the legalisation of same sex marriage in about 21 countries, the scope of marriage has widened. Gay or homosexual marriage as it is sometimes referred to, has elicited emotions because of its very nature. However, from the perspective of most religions, marriage is a divine mandate between a man and a woman. Common law, traditions and religions view marriage as the basis of the family unit and vital for the preservation of morals and civilizations.

Christian and Muslim beliefs hold that, God made a woman from the bone of a man and they were instructed to multiply and subdue the earth. To many scholars of theology, the act of taking the bone from the side of the man is symbolic. It represents the complementary nature of marriage. They claim that God does not want a woman to rule over the man as such, He did not take the bone from the head of the man, neither did He want the woman to be trampled upon by the man hence; He did not take the bone from the foot of man. The role of man and woman in marriage is thereby, complementary. The woman complements the role of the man as a helper (helpmate) such as the neck in its complementary role, supports the head. As apologetic as this design argument seems, the 
traditional arrangement that had the husband's role defined as; providing shelter, food, housing and protecting his household from external aggression, contributed immensely to human flourishing as everyone understood and accepted marriage as mandatory for procreation and companionship. However, the abuse of power and position by the dominant group in the society, led to discrimination, oppression and violence against women who are considered inferior. In a patriarchal society, culturally embedded practices empower men with authority and protect their interest while women are discriminated against, dehumanized and coerced into acts that originally they would not have done. According to Isibor (2008), "when they were not making babies or performing domestic chores and tilling the soil, they are faded into anonymity. They could not own land; they could not hold titles in a society where titles were the ultimate testimony of self- actualisation. They were merely pieces of property owned by the men and thus, subject to whatever use they were put into." Women became dissatisfied with the lopsided arrangement. In time, the struggle for emancipation from oppression and marginalisation resulted into feminist movements. According to GLAD (2015), "certain elements that were once considered essential or natural to marriage - women as subordinate to men; marriage as a lifelong institution; that it must be between people of the same race; have fallen away based on the growing respect for equality and individual freedom."

For several years, gay and lesbian activists have confronted the legal system -mainly the courts- demanding that it ends its discrimination against same sex marriages (Eskrigde, 1993). One of the arguments made in support of their demands is that State refusal to recognize same sex marriage violates the right to marry. The US Supreme Court on June 26, 2015, issued a ruling granting same sex couples the constitutional right to marry (Masci and Motel, 2015). With this decision, US joins twenty other countries that already allow gay and lesbian couples to wed in all their jurisdictions (Masci and Motel, 2015). These countries include, Netherlands, Spain, France, all of Scandinavia, Ireland, Argentina, Brazil, Canada, New Zealand, South Africa and Uruguay, as well as parts of Mexico (Masci and Motel, 2015). Proponents of same sex marriage contend that same sex couples should have access to all benefits enjoyed by heterosexual couples. Opponents of same sex marriage reason that, 
same sex marriages are not marriages because the purpose of marriage is procreation, which same sex couples cannot accomplish. Proponents of same sex marriage argue that assisted reproductive technology including cloning can be used to help same sex couples fulfill their wish to parent and nurture children.

With the legislation of same sex marriages, more gay and lesbian couples would want to have their own biologically related children. The importance of children in marriage and society cannot be over emphasized. Having one's own child gives a sense of fulfillment in marriage and a feeling of social acceptance as same sex parents participate in the same activities as heterosexual parents. Infertility is one problem that can be addressed through other means like adoption and the use of assisted reproductive technology such as in-vitro fertilization, in-vivo fertilization and surrogacy. With these, there is no compelling reason for denying same sex married couples the liberty/ right to reproduce.

\section{Artificial Methods of Procreation}

Same sex couples could use assisted reproductive technologies to found their own families. Some forms of artificial reproductive methods are:

\section{Cloning}

According to the National Human Genome Research Institute (2015), the term cloning describes a number of different processes that can be used to produce genetically identical copies of a biological entity. The copied material, which has the same genetic makeup as the original, is referred to as a clone. According to this report, there are different types of artificial cloning: gene cloning, reproductive cloning and therapeutic cloning.

Gene cloning produces copies of genes or segments of DNA. Reproductive cloning produces copies of whole animals. Therapeutic cloning produces embryonic stem cells for experiments aimed at creating tissues to replace injured or diseased tissues. Gene cloning, also known as DNA cloning is a different process from reproductive and therapeutic cloning. Reproductive and therapeutic cloning share many techniques, but are done for different purposes (National Human Genome Research Institute). 
Gene cloning techniques are used to make copies of genes that scientists wish to study. The procedure according to National Human Genome Research Institute (2015) consists of inserting a gene from one organism, often referred to as "foreign DNA", into the genetic material of a carrier called vector. After the gene is inserted, the vector is placed in laboratory conditions that prompt it to multiply, resulting in the gene being copied many times over. Reproductive cloning on the other hand requires that a mature somatic cell be removed from an animal that is to be copied. The DNA of the donor somatic cell -such as the skin cell, is transferred into an egg cell or oocyte that has its own DNA- containing nucleus removed. According to National Human Genome Research Institute (2015), there are two ways of adding the DNA from the somatic cell to the empty egg. In the first method, they remove the DNA- containing nucleus of the somatic cell with a needle and inject it into an empty egg. In the second approach, they use an electrical current to fuse the entire somatic cell with the empty egg. In both processes, the egg is allowed to develop into an early-stage embryo in the test tube and then implanted into the womb of an adult female animal. Through this processes, the adult female gives birth to an animal that has the same genetic make-up as the animal that donated the somatic cell. Reproductive cloning may require the use of a surrogate mother to allow development of the cloned embryo (National Human Genome Research, 2015).

\section{In vitro Fertilization (IVF)}

In vitro fertilization covers all technologies where fertilization takes place outside the body of a woman. In vivo fertilization on the other hand, refers to fertilization inside the woman's body (in a living situation). In in-vitro fertilization or test tube baby, an egg is fertilized by a sperm (creating the zygote) and transferred into the uterus. It creates a progeny similar to normal conception. The child carries the DNA of both parents (Singh, 2013). It is an in vitro process that gave birth to the first test tube baby Louise Brown in 1978. It is one of the major treatments for infertility and offers lesbian couples the opportunity to co-create a child. 


\section{Artificial Insemination (AI)}

Artificial insemination refers to the injection of semen from either the woman's partner or donor, by artificial means (usually a syringe) into a woman's uterus for the purpose of achieving pregnancy (Simpson, 1998). Where sperm from a donor is used, the procedure is called donor insemination. According to Simpson (1998), artificial insemination is employed in cases of male fertility. It is also used where the male partner is a carrier or victim of inheritable disease. The woman is artificially inseminated and the normal process of fertilization and pregnancy follows.

\section{Surrogacy}

As a form of Assisted Reproductive Technology, surrogacy is relatively new. It arose as a viable form of Assisted Reproductive Technology with the advent of new technology that allowed the creation of an embryo with the surrogate's egg and the father's sperm but without need for sexual intercourse (Lorillard, 2010). Surrogacy has been traced back to the Old Testament by writers who cite the story of Abraham, Sarah and her handmaid Hagar as an example of surrogacy. Accordingly, Sarah motivated by a desire to have children through Hagar persuaded her husband, Abraham, to have intercourse with her handmaiden, Hagar. When the child was born, he was raised by Abraham and his wife Sarah. According to Lorillard (2010), before the advent of surrogacy contract, the practice of surrogacy was an altruistic one, with the surrogate usually a friend or a family member. She states that, in the procedure called "traditional surrogacy", the surrogate is artificially inseminated and then carries the child to term, relinquishing her parental rights to the child's natural father. The father's wife may then adopt the child in a proceeding referred to as step-parent adoption.

"Gestational surrogacy" is a form of surrogacy in which the surrogate is implanted with an embryo that is a product of in vitro fertilization. The embryo consists of the "combined gametes" of two others, who may be third party donors, the husband and the wife seeking the surrogate's services, or a combination of the two (Lorillard, 2010). 


\section{Adoption}

Adoption is an ancient and widespread human practice that continues to flourish in modern societies. Evidence abound that without ties of genetic kinship, one can incorporate children successfully into families by legal adoption (Callahan, 2015).

\section{The Difference between In-vitro Fertilization and Cloning}

In in-vitro fertilization an egg is fertilized by a sperm (creating the zygote) and transferred into the uterus. During IVF, the oocytes (eggs) and the sperm are combined in a culture dish in laboratory. Fertilization and very early embryo development occur outside the body, rather than in the fallopian tube. Once early embryo development is confirmed, the embryos are transferred either into the uterus or the fallopian tube (The University of Texas Health Science Center, 2015). However in cloning, a somatic cell is taken from a donor and used to create an embryo. This child is born to a single parent and only carries his/her DNA. In other words, there be no need for gamete donors (men and women who donate sperm and eggs). According to Singh (2013), biologically, a child from IVF is a unique human (unless he/she has an identical twin) while a cloned child is genetically identical to his/her parents. While this method will be largely beneficial to lesbians, their male counterpart, may need the services of a surrogate mother to allow development of cloned embryos. Cloning could make it possible for lesbian couple to have a baby using the egg from one woman and the gene from the other, doing away with the need for artificial insemination (Simpson, 1998). IVF on the other hand, offers lesbian couples the opportunity to co-create a child. According to Daar (2013), if both women wish to contribute to the reproductive process, one woman can supply (Genetic mother) and the other can gestate the fetus (the birth mother).

\section{Advantage of Cloning over other Methods}

Cloning does not involve the practice of gamete donation as such dilemmas resulting from such practice are avoided. For instance, donor-conceived children may demand to know their genetic parents. According to Sabatello (2015), an increasing number of countries have further reversed the long held policy of gamete donors anonymity, collecting gamete donors' identifying 
information and requiring their consent to be contacted in the future by any resulting donor-conceived child. Some parents, who may not want to disclose the identity of the gamete donor to their children, may find this disturbing. Again, a donor-conceive child may show medical symptoms which maybe the result of a genetic condition that the child inherited from the donor but retrieving information on the donor may be difficult.

\section{Effects of Human Cloning}

In legalising same sex marriage, human cloning becomes morally justifiable. Same sex couples cannot be denied the "goods" of marriage particularly as procreation is essential to the continuity of a people as well as the growth and development of any nation. However, studies on animal cloning indicate that, the risks of cloning outweigh the benefits if used on human beings. The consequences connote pains, miscarriages as well as deaths of both children and mothers. According to Shalev (2002), most animal attempts (as many as 90\%) are unsuccessful. Many of the clones die or are abnormal. Shalev (2002) observed that the procedures used and the oversized fetuses produced, put carrying mothers at risk. Miscarriages are depressing for most mothers who bond with their babies during pregnancy and the death of loved ones can be devastating. According to Di Berardine (1998), even if cloning from adult cells did become efficient, there still would be serious hazards. Among other concerns, is that life span of the clone is unknown. Scientists do not fully understand the cellular aging process. They do not know for instance, which "age" or "genetic clock" Dolly the sheep inherited (Andrews, 1998). In other words, clones can be short lived and regarded as disposable copies. The cloning process and its product, create a lot of anxiety for those involved. The states of anxiety and depression exert pressure on people's health. According to Andrews (1998), studies of people's responses to genetic testing information show that learning genetic information about oneself (whether it is positive or negative information), can harm one's self image. He argued that an individual might be stigmatized or discriminated against based on fore knowledge of her genotype.

Although cloning could be said to contribute to a "good" in marriage - procreation, it does not capture the core of human happiness in marriage. Parenting is encompassing. It includes the joy 
of one's children as healthy, able bodied persons who can care for their parents when they are old and feeble. The ability of children to cater for themselves even after their parents are gone contributes immensely to the joy of parenting. Cloning certainly has its drawbacks, but so do other artificial reproductive methods. For instance, recent research has suggested that the use of fertility drugs maybe associated with an increased risk of developing ovarian cancer in life (Hudson Valley Fertility, 2006:2). Ovarian cancer is a life threatening disease. For women over the age of fifty years the annual risk is about 50/100,000. Multiply pregnancy is a serious risk of Assisted Reproductive Technology treatment. Additional risks associated with multiple pregnancies include pre-term labour, preterm rupture of membranes and intrauterine growth restriction. These complications may be associated with a higher risk of lung disorders and neurological or developmental problems (Hudson Valley Fertility, 2006:2).According to the Assisted Fertility Org. (16), ovarian hyper stimulation is another risk associated with assisted reproductive technology. Occasionally, a woman's ovaries over-respond to fertility injections and produce too many eggs (follicles). If this occurs and treatment continues it notes, there is the risk of ovarian hyper stimulation syndrome (OHSS). Fluid can accumulate in abdomen, tissues and sometimes in the chest cavity. When this fluid accumulation is severe, it could lead to hospitalization and possible drainage of excess fluid from the abdomen or chest. Reported complications, while extremely rare, have included blood clots, kidney failure, fluid overload, and death (Hudson Valley Fertility, 2006:4). Despite these setbacks in assisted reproductive technology, 500 children are born each year through the means of IVF (The CornerHouse, 1999). The demand for children among same sex couples is expected to increase with the legalization of same sex marriage.

\section{The Ban on Cloning and its Effects on Scientific Inquiry and Commerce}

The Human Cloning Prohibition Act of 2001 bans human cloning for reproductive and experimental purposes. It bans the participation in human cloning and the importation of products derived from this technique. A prohibition on cloning interferes with the freedom of science. According to Shalev (2002), The Universal Declaration on 
Human Right (UDHR) includes the right to the 1966 International Covenant on Economic, Social and Cultural Rights (ICESCR), States undertake to respect "the freedom indispensable for scientific research". Early discovery promises that human genome technology has the potential to help solve numerous medical problems that relate to aging, replacement of human parts, infertility and what is viewed as incurable diseases (Williams, 2007). For scientists, the quest for advancement in knowledge and cures to diseases drives the demand for a lift in the ban on cloning. While the idea of cloning a human being raise various concerns, the knowledge on human cloning remains largely unused, if it cannot be tested on humans.

A ban on cloning is not in the interest of many biotechnology companies that look forward to making multimillions of dollars from cloning-a market driven by demands for clones by infertile people, those who have lost their loved ones, gays and lesbians who want their own children, people who want to clone themselves or family members, those who need cloned organs, and of numerous other client categories (Best and Keller, 2006), who would pay any amount to have what they want. The State's interest in marriage should be to channel responsible procreation but some governments serve as leading actors in the international reproductive tourism market. While the idea of cloning a human being raise various concerns, the knowledge on human cloning remains largely unused, if it cannot be tested on humans (Williams, 2007). The supposed effects of cloning on humans are merely claims that have not been authenticated as long as it has not been tested on humans.

\section{Legalisation of Same Sex Marriage and Issues Related to the Ban on Cloning}

In the view of some writers like Lori Andrew (n.d), government's decision to ban cloning can be challenged on a number of constitutional grounds. Firstly, a ban on cloning is not justified under the commerce clause. Secondly, it violates scientists' First Amendment Freedom of Inquiry. It violates a couple's or individual's constitutional right of privacy or liberty to make reproductive decisions. On the other hand, some writers like Taylor (2003) are of the view that the government has a right to regulate and in some cases, limit these rights if government's interest in protecting viable human embryos and the potentiality of human life 
is stronger than the rights to cloning. In his opinion, even if a constitutional right to procreate exists, it might not include procreative cloning. Procreative cloning differs from all other human reproduction- it is asexual, and does not create a new DNA. In the view of this work, it is the unique nature of gay or homosexual marriages- which differs from the traditional, male and female marriage that necessitates a different approach to reproduction among them. The act of legalizing a man to man or a woman to woman marriage that cannot yield to natural procreation, constructs homosexuals as human beings that can and should reproduce asexually. Cloning is therefore in the best interest of same sex couples. By legalising same sex marriage, a situation where lesbians and male gays will largely depend on cloning for genetic children of their own, is created. Despite the use of other methods, cloning affords lesbians particularly, and male gays - with the help of surrogates, the opportunity of having children with the same DNA. The Corner House (1999) puts it this way, “... people attach value not simply to raising children, but above all to raise children which they have begotten or borne". Having children with the same DNA makes them not just copies of you but you. For instance, in Genesis 2:21-22, we are told that God put a deep sleep on Adam and this enabled Him to take a rib from his side in making a woman. When Adam saw the creature, he said, "This is now the bone of my bones and the flesh of my flesh." An African adage says, you cannot expose a part of your body in public and begin to lash it. What this implies is that, there is the tendency to protect and love what is yours. By legalising same sex marriage the onus of lifting the ban on cloning has been placed on same sex couples who can demand that their rights to procreation and privacy be respected.

According to Shalev (2002), medical research may be carried out only within the legal protections guaranteed to the individual human subjects, primarily the right to consent freely to participate in medical research. If the State does not have the right to intrude into the decisions of same sex couples on reproduction then, the ban on cloning will be removed. Same sex couples as well as infertile couples can give their consent to participate in medical researches on cloning in order to have their own children. With the removal of the ban on cloning, scientists can experiment their researches on animal cloning using human beings. Because cloning 
is asexual reproduction it will help scientists achieve the desire to reduce their need for industrial supplies of human eggs. Demand for gamete donors will be reduced.

Legalisation of same sex marriage also gives a moral justification to cloning. It will be unjust to deprive same sex couples the opportunity of having children who share the same lineage as them. In places like Africa, a great value is placed on the kinship system. A woman cannot inherit her husband's property because she does not have a blood tie with him but a brother can inherit his late brother in cases where there are no children. Adopted children in such instances, do stand not the chance of inheritance. They are regarded as strangers with no blood tie to the family, thus no right to inheritance. Neither can children borne from insemination with donor sperm be regarded as "part of the family" because their family backgrounds are unknown. In Africa, ancestral lineage is a serious issue because it helps people to construct the other's identity, worth, and capabilities in a given community.

The legalisation of same sex marriage and the rights to procreation and privacy that it guarantees, would lead to the attainment of medical and commercial benefits attached to cloning technology if, same sex couples fight for their rights. Removing the ban on cloning will also benefit the government since human cloning and related techniques can provide new sources of power and control to State and Medical institution (The CornerHouse, 1999).

\section{Objectification in Same Sex Couples Situation}

Kant views objectification as involving the lowering of a person, a being with humanity to the status of an object (Stanford Encyclopedia of Philosophy, 2014). For Kant, humanity must never be treated merely as a means, but always at the same time as an end (Stanford Encyclopedia of Philosophy, 2014). A lot of scholars agree that objectification is a notion central to feminist theory. Accordingly, Nussbaum (1995) identified seven features that are involved in the idea of treating a person as an object. These are: instrumentality- this is the treatment of a person as a tool for the objectifier's purposes; denial of autonomy; - the treatment of a person as lacking in autonomy and self determination; inertness the treatment of a person as lacking in agency and perhaps also in activity; fungibility- the treatment of a person as interchangeable 
with other objects; violability- the treatment of a person as lacking in boundary and integrity; ownership- the treatment of a person as something that is owned by another; denial of subjectivity- the treatment of a person as something whose experiences and feelings (if any) need not be taken into account (Stanford Encyclopedia of Philosophy, 2014).

The process of instrumentality began with the legislation of same sex marriage. A community of "infertile married persons" are created and projected as the basis for cloning. These so called infertile persons are not barren. Some of them have children from previous marriages in heterosexual relationships. To be legally married leads to expectations of raising and nurturing children. This intensifies social pressure to conform to the available options of having children. The implication of this is that, by recognizing as eligible for marriage, people who are naturally unfit for procreation, a situation where such persons become dependent on reproductive cloning to have children who are biologically related to them is created. Unfortunately, children of this make, still remains product of their "makers" (scientists). Their progress is closely monitored while their activities are restricted and streamlined to routine procedures.

According to Stanford Encyclopedia of Philosophy (2013), "cloning for research and therapy requires a large number of donor oocytes...Unlike women who are considering IVF, non-medical oocyte donors are not clinical patients. They do not stand to derive any reproductive or clinical benefit themselves from the donation." In creating a "pool of artificial infertile persons," scientists are provided with victims willing to consent to their involvement in the on - going medical research on cloning. What this implies is that, scientists can now advance in their studies of animal cloning to human cloning despite its harmful effects. They exploit the dependency status of same sex married couple on cloning for procreation to improve on their researches. Those who favour human cloning regard such scientific advancement as necessary for human improvement but what they never stopped to ponder on, is the enormous sacrifice it entails. Designing this "sacrifice" as the responsibility of a particular group of persons is deceitful, coercive, exploitative and discriminatory. Consent in this condition, cannot be regarded as true consent. Resorting to cloning seems to be the only 
Ehiemua \& Adeyemo: Legalising same sex marriage and coning

viable way to have genetically related children and gain social acceptability and respect.

\section{Implication}

There is a potential threat to the "world" of same sex couples. The legislation of same sex marriage makes them out as "endangered species" that must depend on cloning for reproduction of genetically related children. Their vulnerability will be exploited by scientists who need human beings to experiment on and large number of oocytes donors for cloning research.

\section{Conclusion}

The legislation of same sex marriage give room for the manipulative use of same sex couples for the furtherance of scientific researches even when it is harm causing. An argument in favour of reproductive cloning technology is that, it is a possible way of saving endangered species and a means through which homosexual couples can have biologically related children. Some views hold that, because cloning maybe the only way some people can procreate, to deny cloning to these people would be a violation of procreative liberty. For same sex couples having children can be empowering and fulfilling but then there are enormous risks involved in the process of cloning. Moreover, cloning could be misused and abused. The manipulative use of legislation to create a pool of "infertile persons" for scientists use exposes such people to the harmful effects of cloning. This is dehumanizing and an abuse of power particularly as, the government is supposed to prevent people from self inflicted harm. Because cloning is largely unsafe, it is proper that caution against misuse and abuse should be strictly adhered to.

\section{Policy Recommendations}

Based on the findings of this study, the following are recommended:

- Safety concerns on human cloning should be addressed through animal cloning technology

- The ban on cloning should be in place until risks involved are minimized

- Participants in cloning researches should be educated on the risks involved 
- Cloned humans cannot be totally taken to be natural humans and are therefore bound to exhibit certain traits that are inimical to public health and interest; hence the ban on human cloning should be sustained.

* Gloria Faith Ehiemua (PhD), Department of Philosophy and Religions, University of Benin, Benin City -Edo State, fehiemua@gmail.com or Faith.ehiemua@uniben.edu

* Lateef Kayode Adeyemo (PhD), Department of Philosophy and Religions, University of Benin, Benin City - Edo State lateefadeyemo@gmail.com or lateef.adeyemo@uniben.edu 


\section{References}

Andrews Lori. Cloning Human Beings: the Current and Future Legal

Status of Cloning. Commissioned Paper, Chicago- Kent College of Law

Andrews, Lori. "Is There a Right to Clone? Constitutional Challenges to Bans on Human Cloning", Harvard Journal of Law \& Technology 1.3 (1998): 5-24

Berardino, Marie. "Cloning: Past, Present and the Exciting Future:

Breakthrough in Bioscience" Researchgate (1998)

www.researchgate.net/publication1234640995 Cloning_Fut

ure_Breakthroughs_in_Bioscience 2 Sept. 2015

Best Steven and Kellner Douglas. Biotechnology, Ethics and the

Politics of Cloning, $2006 w w w$.

Bibliotecapleyades.net/.../ciencia_

Callahan Sidney. "The Ethical Challenges of the New Reproductive

Technologies", Health Care Ethics, 2015

Samples.jbpub.com/.../chap4pdf

Cloning Human Beings Report and Recommendations of the Nat'l

Bioethics Advisory Commission, Executive Summary1

(1997),http://bioethics.georgetown.edu/nbac/pubs/cloning/e xecutive.htm

Daar, Judith, "Accessing Reproductive Technologies: Invisible

Barriers, Indelible Harms", 23 Berkeley J. Gender L \& Just, 18 (2013).

http://scholarship.law.berkeleyedu/bglj/vol23/Iss1/2

Devolder, Katrien, "Cloning." The Stanford Encyclopedia of

Philosophy (Summer 2013 Edition). Edward N. Zalta (ed.),http://plato.stanford.edu/archives/sum2013/entries/

Eskridge, William N. Jr. "A History of Same Sex Marriage" 1993

Faculty Scholarship Series Paper 1504.

http;//digitalcommons.lawyale.edu/fss-Papers/1504

GLAD, "Marriage- A History of Change" (2015):

https://www.glad.org/rights/.../c/ marriages. 3 Sept. 2015

Hudson Valley Fertility. Consent for ART, 2006, www.

Hudsonvalleyfertility.com/.../Hudson-Valley-Fertility-

Consent-for-ART-pdf

Isibor P.O. "Women's Right and Status under Edo Native Law and

Custom: Myth and Realities" (1), Edo World (2015): 
http://edoworld.net/Women_Right_And_Status, accessed September 1, 2015

Lorillard Christine. Informed Choices and Uniform Decisions: Adopting the ABA's Self-Enforcing Administrative Model to Ensue Surrogacy Arrangements. Cardozo Journal of Law and Gender

Manninen, Bertha. "Cloning”, Internet Encyclopedia of Philosophy (2015): www.rep.utm.edu/cloning, 2 Aug. 2015

Masci, David and Motel, Seth. "5 Facts about Same Sex Marriage" Pew Research Centre (2015): www.pewresearch.org/facttank/2015. 5 Aug; 2015

Maya Sabatello. "Regulating Gamete Donation in the U.S.: Ethical, Legal and Social Implications" Laws 2015, 4,325-376 www.mdpi.com/journal/laws/regulatinggametedonationinu.s :Ethical, legal and social implications

National Human Genome Research Institute. Cloning Factsheet 2015

http://www.ncbi.nlm.nih.gov/Class/NAWBIS/Modules/Gene Expression Variation/varex48.html

Papadaki, Evangelia. "Understanding Objectification: Is There Special Wrongness Involved in Treating Human Beings Instrumentally" Prolegomena 11 (1) 2012: 5-24

"Feminist Perspectives on Objectification", The Stanford Encyclopedia of Philosophy (Summer 2014 Edition), Edward n. Zaita (ed.), http://plato.stanford.edu/archives/sum2014/entries/feminism -objectification/>

Parella Fred. "Gay Marriage: Theological and Moral Arguments", Santa Clara University Markkula Center for Applied Ethics, 2004 www.scu.edu/ethics/publications

Robertson, John. "Gay and Lesbian Access to Assisted Reproductive

Technology" Case Western Reserve Law Review 55.2 (2004): 323-372 http://law.utexas.edu/.../

Schneider David. Ethics - Introduction from a Religious Perspective: the Direction of New Laws. www.rpi.edu/dept/.../bioethics.html

Shalev, Carmel. "Human Cloning and Human Rights: A Commentary." Health and Human Rights 16.1 (2002): JSTORwww.jstor.org/stable/4065317. 4 Aug. 2015 
Ehiemua \& Adeyemo: Legalising same sex marriage and coning

Singh Sonal. "What is the Difference between Test Tube Baby and a Clone", 2013. https:www.gnora.com/what-is-the-differencebetween-a-test-tube-baby-and-a-clone

Simpson Rachel. Assisted Reproductive Technology: Background Paper, No 6/98 www.parliament.nsw.gov.au/.../bp06-98

Taylor, Rogers. "The Fear of Drawing the Line at Cloning" 9, B.U.J. $\begin{array}{llllll}\text { SCI } & \& & \text { Tech. } & \text { L } & 379,398 & 2003\end{array}$ http://www.bu.edu/law/..taylorpdf

The CornerHouse. "If Cloning is the Answer, What was the Question: Power and Decision Making in the Geneticisation of Health" (1999), http://www.thecornerhouse.org

The University of Texas Health Science Center. IVF Manual Uthscsa.edu/whc/secure/IVF-Manual.pdf

Wex Legal Dictionary/Encyclopedia. "Marriage" Cornell University Law School (2015): www.law.cornell.edu/wex/marriage. 4 Aug. 2015

Williams Carolyn. Human Cloning, Genetic Engineering and Privacy, Yale-New Haven Teachers Institute www.yale.edu/ynhti/00.0607html 